\title{
Biological activity and magnetic resonance imaging of superparamagnetic iron oxide nanoparticles-labeled adipose-derived stem cells
}

\author{
Jingjing Fan, Yanbin Tan, Liyong Jie, Xinying Wu, Risheng Yu and Minming Zhang*
}

\begin{abstract}
Introduction: No comparative study of adipose-derived stem cells (ADSCs) and bone marrow mesenchymal stem cells (BMSCs) by using superparamagnetic iron oxide nanoparticles (SPIOs)-labeling and magnetic resonance imaging (MRI) has been performed.

Methods: We studied the biological activity and MRI of ADSCs by labeling them with SPIOs and comparing them with BMSCs. After incubating the cells in culture medium with different levels of SPIOs (control group: $0 \mu \mathrm{g} / \mathrm{ml}$; Groups 1 to 3: 25, 50, and $100 \mu \mathrm{g} / \mathrm{ml}$ ) for 24 hours, we compared ADSCs with BMSCs in terms of intracellular iron content, labeling efficiency, and cell viability. Stem cells in the culture medium containing $50 \mu \mathrm{g} / \mathrm{ml} \mathrm{SPIOs}$ were induced into osteoblasts and fat cells. Adipogenic and osteogenic differentiation potentials were compared. $\mathrm{R}_{2}{ }^{*}$ values of MRI in vitro were compared.

Results: The results showed that labeling efficiency was highest in Group 2. Intracellular iron content and $\mathrm{R}_{2}{ }^{*}$ values increased with increasing concentrations of SPIOs, whereas cell viability decreased with increasing concentrations of SPIOs, and adipogenic and osteogenic differentiation potentials decreased. However, we found no significant difference between the two kinds of cells for any of these indexes.
\end{abstract}

Conclusions: ADSCs can be labeled and traced as easily as BMSCs in vitro. Given their abundance and higher proliferative capacity, as was previously shown, ADSCs may be better suited to stem cell therapy than are BMSCs.

Keywords: Adipose-derived stem cells, Bone marrow mesenchymal stem cells, Superparamagnetic iron oxide nanoparticles, Magnetic resonance imaging

\section{Introduction}

Mesenchymal stem cells (MSCs) appear to be ideally suited for therapeutic use in tissue repair and many other diseases that are able to differentiate into various types of tissue cells derived from other embryonic layers [1-3]. Bone marrow mesenchymal stem cells (BMSCs) were the first MSCs used for laboratory research [4]. However, conventional bone marrow procurement procedures are distressing for the patient and yield a low number of MSCs. Bone marrow fat increases with age, which often means a sufficient number of MSCs cannot be extracted. Many studies have thus investigated alternative sources to bone marrow for MSCs.

\footnotetext{
*Correspondence: cjr.zhangminming@vip.163.com

Department of Radiology, 2nd Affiliated Hospital, Medical College, Zhejiang University, 88 Jiefang Road, Hangzhou 310009, China
}

Adipose tissue, like bone marrow, is derived from the embryonic mesenchyme and represents a rich source of MSCs [5]. Many studies have compared various aspects of cell biology between the two kinds of stem cells. Taléns-Visconti et al. [4] showed that adipose-derived stem cells (ADSCs) have a similar hepatogenic differentiation potential to that of BMSCs, but a longer culture period and higher proliferative capacity. Nakao et al. [3] found that ADSCs facilitate the homing of mouse stem cells to bone marrow better than do BMSCs. Kern et al. [6] found that the proliferative capacity of ADSCs was the highest of all the MSCs. Some researchers have found that ADSCs have lower immunogenicity and immunosuppressive effects, implying a lower rejection and higher success rate in transplantation [7,8]. Furthermore, the number of ADSCs is large and is not affected by age [9],

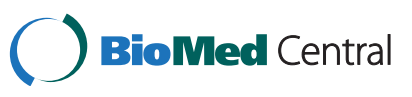

(c) 2013 Fan et al.; licensee BioMed Central Ltd. This is an Open Access article distributed under the terms of the Creative Commons Attribution License (http://creativecommons.org/licenses/by/2.0), which permits unrestricted use, distribution, and reproduction in any medium, provided the original work is properly cited. 
but all the comparisons are in biology aspects. It is not enough for cell choice just to compare the characteristics of these two kinds of stem cells.

Central to the success of stem cell therapy is the ability of cells to migrate and engraft. Magnetic resonance imaging (MRI) is useful for evaluating the ability of cells to migrate and engraft [10-16]. SPIOs have been used to label cells, allowing researchers to monitor cell migration by using MRI in experiments [17-21]. BMSCs were the first kind of MSCs to be labeled with superparamagnetic iron oxide particles (SPIOs) and successfully traced in vivo $[10,11,19]$. Many studies have also used SPIO labeling and MRI to study ADSCs [22-24]. However, a comparative study of ADSCs and BMSCs by using SPIO labeling and MRI has not been performed.

This study investigated whether ADSCs can be labeled and traced as easily as BMSCs, examining the intracellular iron content, labeling efficiency, cell viability, adipogenic and osteogenic differentiation potentials, and MRI of SPIO-labeled ADSCs and compared these with BMSCs, to help guide the selection of cells for stem cell therapy.

\section{Methods}

\section{Preparation of SPIOs}

SPIOs were prepared according to the method developed by Racuciu et al. [25] with some modifications. In brief, an aqueous solution of $4.16 \mathrm{~g} \mathrm{FeCl}_{2} \cdot 4 \mathrm{H}_{2} \mathrm{O}$ and $10.44 \mathrm{~g} \mathrm{FeCl}_{3} \cdot 6 \mathrm{H}_{2} \mathrm{O}$ in $380 \mathrm{ml}$ demineralized water was mixed under vigorous and continuous stirring with 40 $\mathrm{ml} 25 \% \mathrm{NH}_{4} \mathrm{OH}$ as the precipitant. The precipitated black powder was vibrated ultrasonically for 30 minutes. Five grams of citric acid in $10 \mathrm{ml}$ water was then added to the powder, and the temperature was increased to $90^{\circ} \mathrm{C}$ with stirring for 60 minutes. The resulting black powder was washed several times until neutral and removed by decanting. The iron content was measured by using a total iron reagent set (Pointe Scientific, Canton, MI, USA). The shape and bare core size of SPIOs were measured with transmission electron microscopy (TEM) (JEM-1230; JEOL, Japan). The diameter and polydispersity index (PDI) of SPIOs were measured with Zetasizer Nano (S90, Malvern, UK).

\section{Preparation of adipose-derived stem cells}

ADSCs were prepared according to the method developed by Zuk et al. [5] with some modifications. In brief, subcutaneous adipose tissue ( 3 to $4 \mathrm{~g}$ ) was obtained from the inguinal regions of male Sprague-Dawley (SD, Vital River, Beijing, China) rats. The adipose tissue was minced and digested with collagenase I $(2 \mathrm{mg} / \mathrm{ml}$; Worthington Biochemical Corp, Lakewood, NJ, USA) at $37^{\circ} \mathrm{C}$ for 30 to 60 minutes. The digested adipose tissue was filtered twice with a $100-\mu \mathrm{m}$ and then a $25-\mu \mathrm{m}$ nylon membrane to eliminate the undigested fragments. The cellular suspension was centrifuged at $1,000 \mathrm{~g}$ for 10 minutes. The cell pellets were resuspended in cell-culture medium (CCM, DMEM+10\%FBS) and cultivated for 24 hours at $37^{\circ} \mathrm{C}$ in $5 \% \mathrm{CO}_{2}$. Unattached cells and debris were removed, and fresh CCM containing 15\% fetal bovine serum (FBS, Gibco, arlsruhe, Germany) was added to the adherent cells, which were cultured at $37^{\circ} \mathrm{C}$ in $5 \% \mathrm{CO}_{2}$. Cell-surface markers were measured with flow cytometry (Beckman FC500, CA, USA). Passage 4 cells were used for the following experiments.

\section{Preparation of bone marrow stem cells}

BMSCs were isolated from bone marrow as described previously [26]. In brief, the bone marrow was harvested from the femurs and tibiae of the same male SD rats as for the ADSCs. Bone marrow cells were resuspended in phosphatebuffered saline (PBS, Gibco) to a final volume of $10 \mathrm{ml}$ and layered over an equal volume of $1.077 \mathrm{~g} / \mathrm{ml}$ Percoll solution (Pharmacia, Piscataway, NJ, USA). After centrifugation at 2,000 rpm for 20 minutes, the mononuclear cells were recovered and transferred to a 100-mm culture flask (Corning, Schiphol-Rijk, the Netherlands) and incubated $\left(37^{\circ} \mathrm{C}, 5 \%\right.$ humidified $\mathrm{CO}_{2}$ ) with low-glucose Dulbecco Modified Eagle Medium (DMEM, Gibco) containing $0.2 \mathrm{mmol} / \mathrm{ml} \mathrm{L}$ glutamine (Gibco), $100 \mathrm{U} / \mathrm{ml}$ penicillin (Gibco), $100 \mu \mathrm{g} /$ $\mathrm{ml}$ streptomycin (Gibco), $10 \mathrm{ng} / \mathrm{ml}$ epidermal growth factor (EGF, PeproTech, Rocky Hill, NJ, USA), and 10\% fetal calf serum (PAA, Pasching, Austria). Nonadherent cells were removed after 24 hours. Cell-surface markers were measured with flow cytometry. Passage 3 or 4 cells were used for the following experiments.

\section{Magnetic labeling}

SPIOs were preincubated in CCM and antibiotics for 60 minutes at room temperature. The concentrations of SPIOs in cell-culture medium were $25 \mu \mathrm{g} / \mathrm{ml}$ (Group 1), $50 \mu \mathrm{g} / \mathrm{ml}$ (Group 2), and $100 \mu \mathrm{g} / \mathrm{ml}$ (Group 3), whereas a medium without SPIOs was used for the control group. The two kinds of stem cells were incubated in $\mathrm{CCM}\left(37^{\circ} \mathrm{C}, 5 \%\right.$ humidified $\left.\mathrm{CO}_{2}\right)$ for 24 hours.

\section{Prussian blue staining}

Prussian blue staining was used to detect the presence of iron oxide nanoparticles. Cells of Groups 1 to 3 were fixed in 4\% paraformaldehyde for 30 minutes and then detected with Prussian blue staining. In brief, fixed cells were washed 3 times with PBS, incubated for 30 minutes with $2 \%$ potassium ferrocyanide in $6 \%$ hydrochloric acid, and then rewashed 3 times with PBS. Labeled cells were examined under a light microscope to determine intracellular iron oxide distribution. 


\section{Iron content}

Cells labeled as described were washed with culture medium and then washed 3 times with PBS, resuspended in $37 \% \mathrm{HCl}$, and incubated at $70^{\circ} \mathrm{C}$ for 30 minutes. Iron content was determined by using a total iron reagent set. The average iron content per cell was then calculated.

\section{Viability}

To determine cell viability, cells of each group were initially seeded in 96-well plates at 5,000 cells per well. After incubation for 72 hours, cells of each group were assessed by using a standard 3-(4,5)-dimethylthialzo(-z-yl)-2,5di-phenyltetrazoliumbromide (MTT) assay (Sigma-Aldrich, St. Louis, MO, USA) for 4 hours. The supernatant fluid was discarded, and $150 \mu \mathrm{l}$ dimethyl sulfoxide (DMSO, Sigma-Aldrich) was added to every well for 10 minutes with shaking. The light absorption of all cells was measured with an enzyme-linked immunosorbent assay (ELISA) reader (BioTek, VT, USA). Results were expressed as relative ratios versus unlabeled cells.

\section{Differentiation}

Adipogenic and osteogenic differentiation were measured to assess the effect of SPIOs on the transdifferentiation potential of cells. Cells in Group 2 and the control group were subjected to two types of induction (adipogenic and osteogenic).

Cells for osteogenic differentiation were seeded in sixwell plates at $10^{5}$ cells per well with CCM. After they reached $60 \%$ to $80 \%$ confluence, the culture medium was replaced by bone cell-induction culture medium containing 10\% FBS, $100 \mathrm{U} / \mathrm{ml}$ penicillin/streptomycin, 50 $\mu \mathrm{g} / \mathrm{ml} \mathrm{L}$-ascorbate-2-phosphate (Sigma-Aldrich), $0.1 \mu M$ dexamethasone, and $10 \mathrm{mM} \beta$-glycerophosphate in DMEM. The cells were cultured for 2 more weeks. Alizarin red was used to detect matrix mineralization of osteogenic differentiation [18]. Cells were rinsed in PBS, fixed in $4 \%$ formaldehyde, and stained in $1 \%$ alizarin red solution (Rowley Biochemical Institute, Danvers, MA, USA) for 3 minutes. Stained cells were observed under a phase-contrast microscope (Olympus, Tokyo, Japan). To quantify the change in osteogenic potential, the activity of alkaline phosphatase (ALP) was detected by using an ALP enzyme activity kit [27]. Expression levels of Bone Gla Protein (BGP)-mRNA osteogenic markers were measured with real-time polymerase chain reaction (RT-PCR) [27].

Cells for adipogenic differentiation were seeded in sixwell plates at $10^{5}$ cells per well with CCM. After they reached $60 \%$ to $80 \%$ confluence, the culture medium was replaced by adipose cell-induction culture medium containing 10\% FBS, $100 \mathrm{U} / \mathrm{ml}$ penicillin/streptomycin (Sigma-Aldrich), $200 \mathrm{~m} M$ indomethacin (Sigma-Aldrich), $1 \mathrm{~m} M$ dexamethasone (Sigma-Aldrich), $0.5 \mathrm{~m} M$ 3-isobutyl -1-methylxanthine (Sigma-Aldrich), and $10 \mathrm{mg} / \mathrm{ml}$ insulin (Sigma-Aldrich) in DMEM. The cells were cultured for 2 more weeks. Cells were rinsed in $\mathrm{PBS}(\mathrm{PH}=7.4)$, fixed in $4 \%$ formaldehyde, and incubated in $2 \%$ (wt/vol) Oil Red O (Sigma-Aldrich) for 5 minutes. Stained cells were observed under a phase-contrast microscope (Olympus, Tokyo, Japan). To quantify the change in adipogenic potential, the optical-density (OD) values of lipid droplets stained by Oil Red $\mathrm{O}$ were measured. Expression levels of adipocyte Protein 2 (aP2)-mRNA adipogenic markers [28] were measured with RT-PCR.

\section{Magnetic resonance imaging of SPIO-labeled mesenchyme-derived stem cells in vitro}

We then determined the differences between the two kinds of SPIO-labeled cells in MR relaxation time. The two kinds of cells labeled with different concentrations of SPIOs were (a)

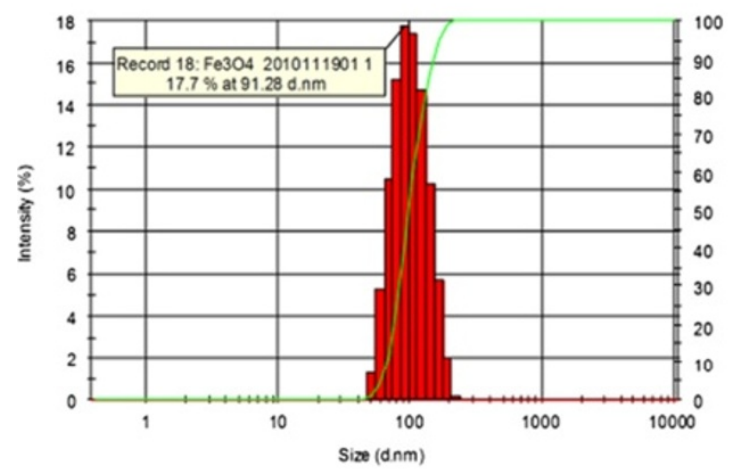

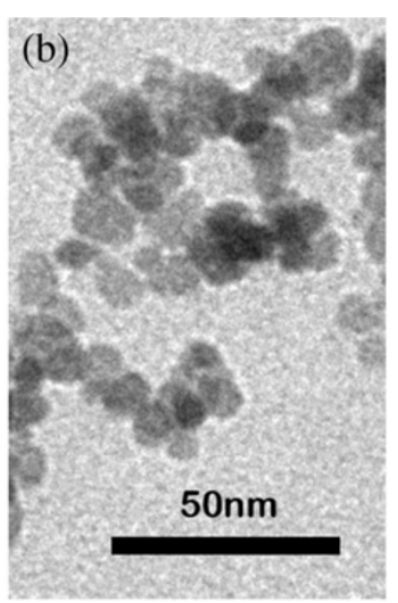

Figure 1 Identification of SPIOs by Zetasizer Nano and transmission electron microscopy (TEM). (a) Diameter and PDI of SPIO measured by Zetasizer Nano. (b) Shape and bare core size of SPIOs measured with TEM. 

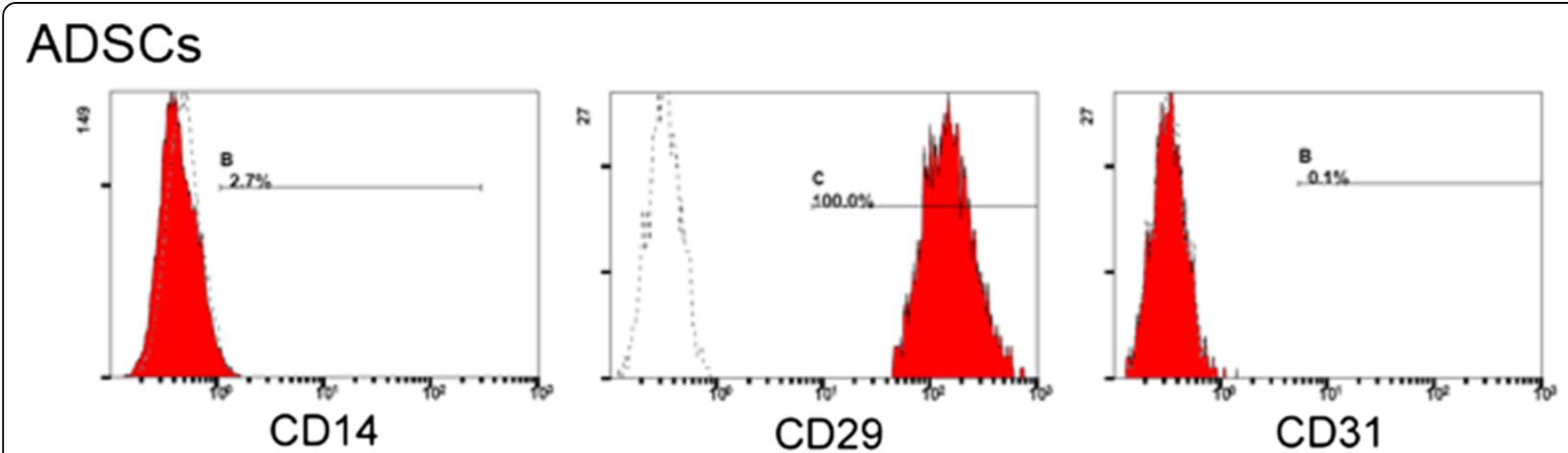

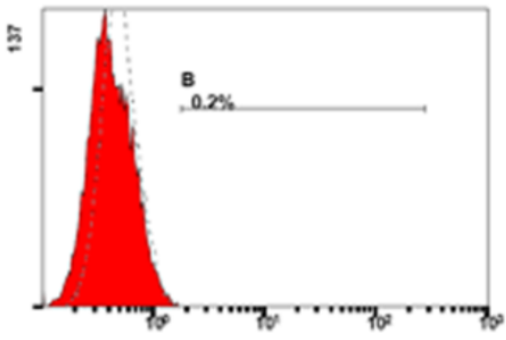

CD34

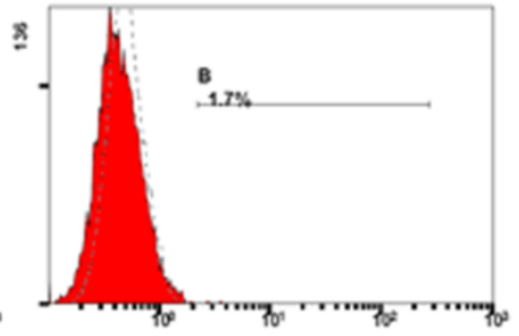

CD45

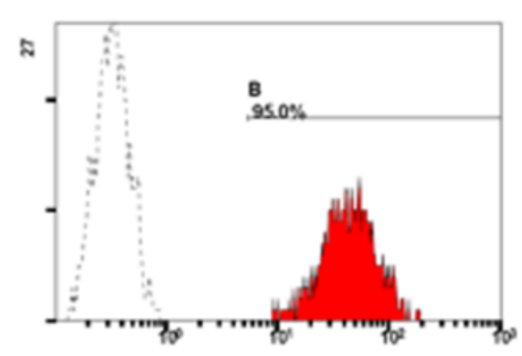

CD90

\section{BMSCs}

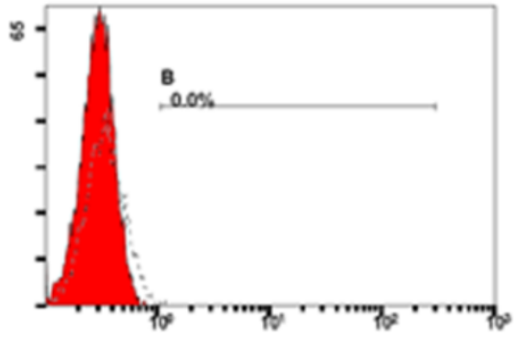

CD14

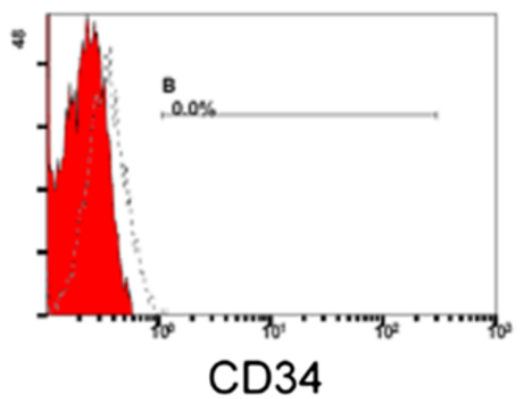

$\approx$

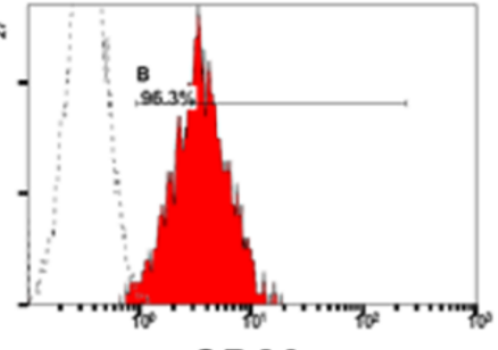

CD29

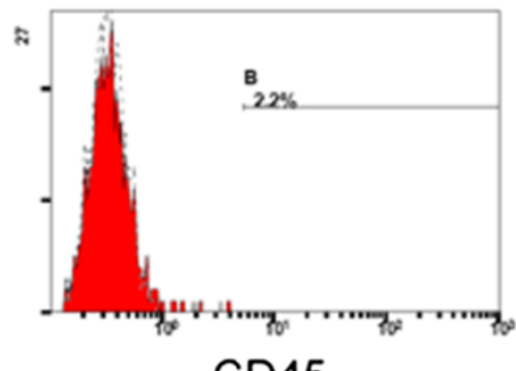

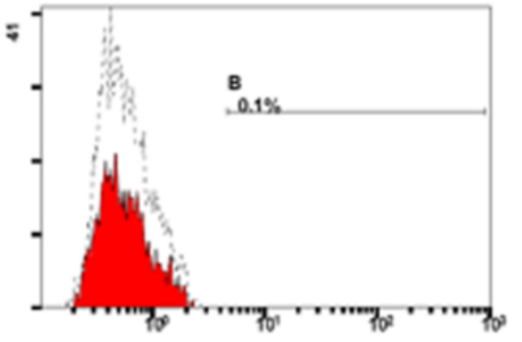

CD31

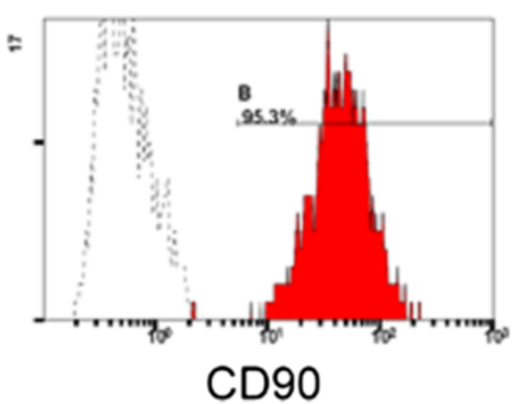

Figure 2 Identification of adipose-derived stem cells (ADSCs) and bone marrow mesenchymal stem cells (BMSCs) with flow cytometry. Flow cytometry revealed that the distribution of ADSCs and BMSCs that stained for CD14, CD31, CD34, and CD45 (shaded regions) did not differ from that of the isotype control (open regions). The majority of cells positively stained for CD29 and CD90 (shaded regions) compared with the isotype control cells (open regions). 

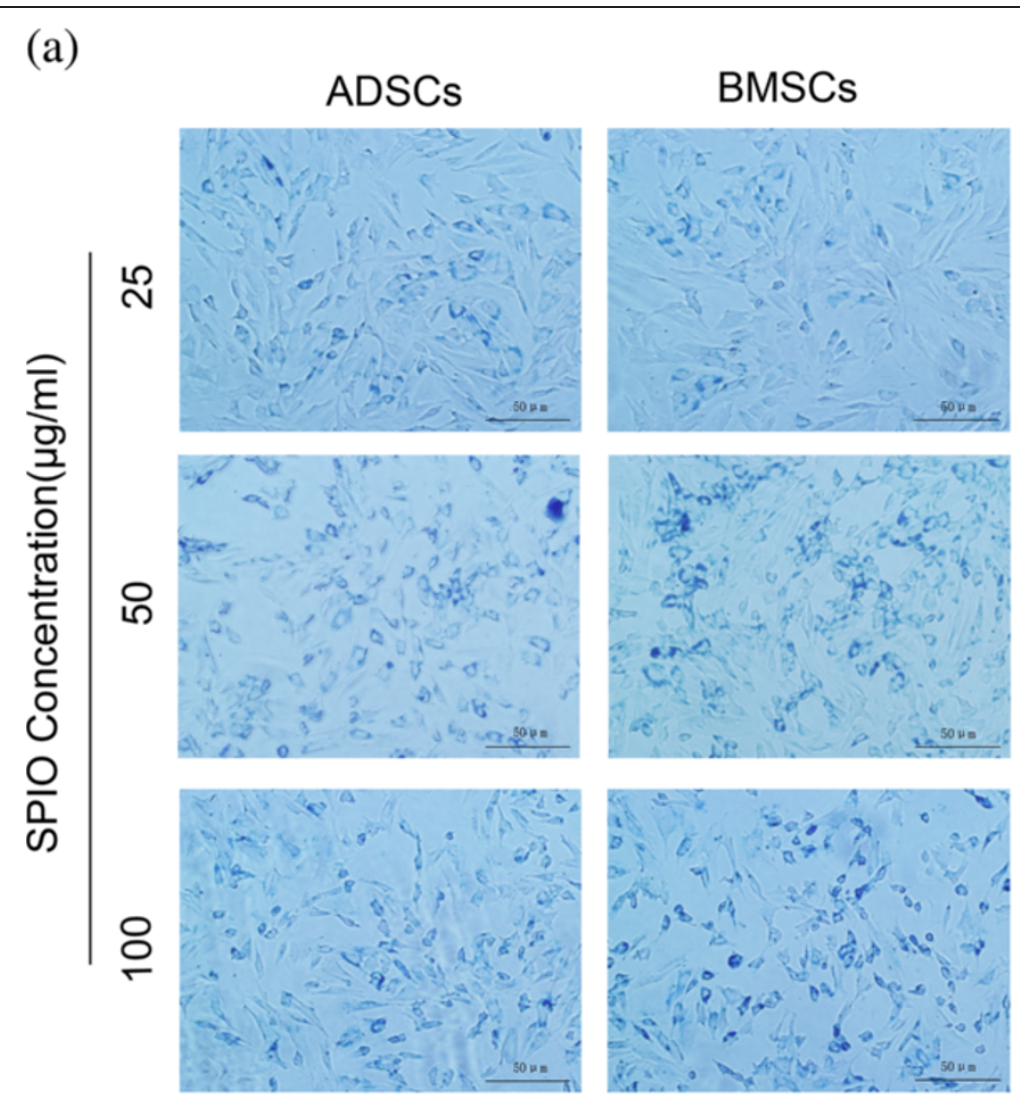

(b)

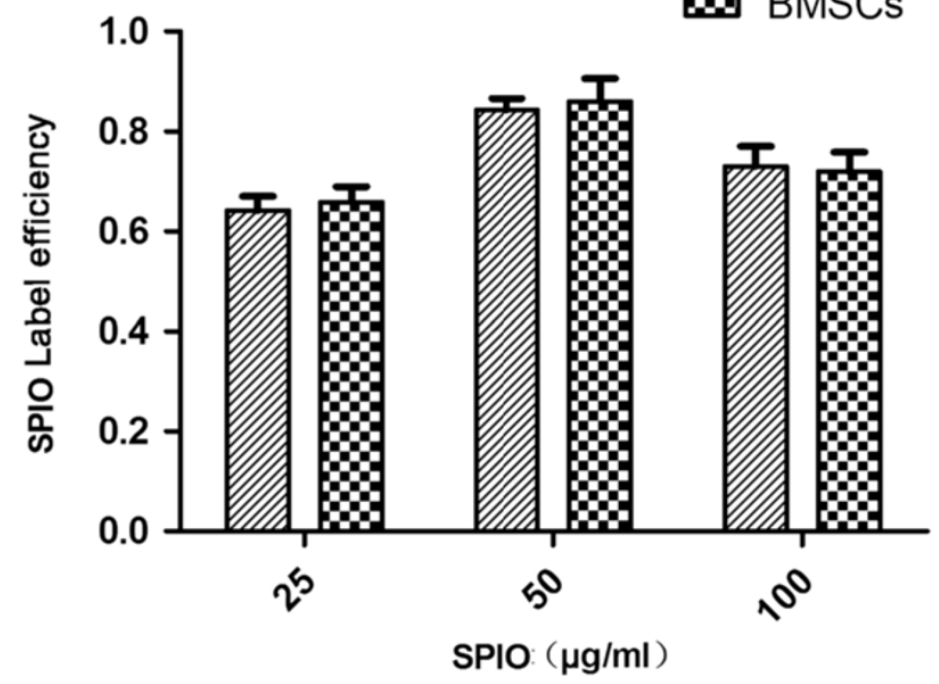

Figure 3 Measurement iron in cells by Prussian blue staining. (a) Adipose-derived stem cells (ADSCs) or bone marrow mesenchymal stem cells (BMSCS) were incubated with different concentrations of SPIOs. Then Prussian blue staining was taken to measure the iron content in ADSCs or BMSCs. Blue particles in cytoplasm are SPIOs. (b) Labeling efficiency of ADSCs or BMSCs in different concentrations of SPIOs. 
suspended in $1 \%$ agarose before being transferred into 1.5-ml microcentrifuge tubes (Eppendorf, Westbury, NY, USA). Each tube contained $1 \times 10^{4}$ cells. The tubes were imaged with an eight-channel phased-array head coil on a 3.0-Tesla MR scanner (GE Signa Excite; GE Medical

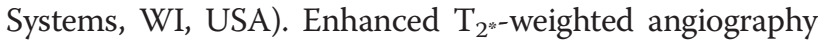
(ESWAN) sequences were used to enhance the $\mathrm{T}_{2^{*}}$ effects of the SPIOs. The sequence parameters were: $\mathrm{FOV}=20 \times$ $20 \mathrm{~mm}^{2}$; matrix $=240 \times 240 ; \mathrm{TR}=45 \mathrm{msec} ; \mathrm{NEX}=0.69$; slice thickness $=2.0 \mathrm{~mm}$; flip angle $=25$ degrees; $\mathrm{TE}=5$ msec, $9.9 \mathrm{msec}, 14.7 \mathrm{msec}, 19.6 \mathrm{msec}, 24.5 \mathrm{msec}, 29.3$ msec, $34.2 \mathrm{msec}$, and $39.0 \mathrm{msec}$.

\section{Data analysis}

Results were analyzed by using the Student $t$ test and one-way ANOVA. $P<0.05$ was considered statistically significant.

\section{Results and discussion}

\section{SPIOs and cells}

The citric-acid-coated SPIOs were brownish-black colloid fluids. The iron content was $22.4 \mathrm{mg} / \mathrm{ml}$. The average diameter of SPIOs was $95.58 \mathrm{~nm}$, and the PDI was 0.101, which means the distribution of the SPIO-diameter stenosis was ideal (Figure 1a). The shape of the bare core of SPIOs was round, and the diameter of the bare core was about 8 to $10 \mathrm{~nm}$ (Figure 1b). CD14,CD31,CD34,CD45 antigens were found to be negatively expressed in labeled cells, while CD29 and CD90 were found to be positively expressed in labeled cells (Figure 2). These cells thus expressed the same cell surface markers as stem cells, so could be identified as stem cells.

\section{Labeling efficiency and intracellular iron content}

After Prussian blue staining, we found blue particles in the cytoplasm of cells. The blue particles were SPIOs surrounding the nucleus (Figure 3a). The labeling efficiency was highest in Group $2(50 \mu \mathrm{g} / \mathrm{ml})$, followed by Group 3 and Group $1(P>0.05)$. The labeling efficiency of the two kinds of cells showed no significant difference (Group 1: $t=1.005, P>0.05$; Group 2: $t=0.860, P>0.05$; Group 3: $t=0.492, P>0.05)$ (Figure 3b).

The intracellular iron content increased with increasing concentrations of SPIOs $(P<0.05)$, but no difference was found between the two kinds of cells (Group 1: $t=0.020 ; P>0.05$; Group 2: $t=0.073 ; P>0.05$; Group 3: $t=0.181 ; P>0.05$ ) (Figure 4). This implies that ADSCs have a similar ability to take up SPIOs to BMSCs. The intracellular iron content of Group 2 ADSCs confirmed that the cells could be clearly traced by MRI in vivo, being above the minimum necessary for MRI ( 5 to 6 pg per cell) $[29,30]$.

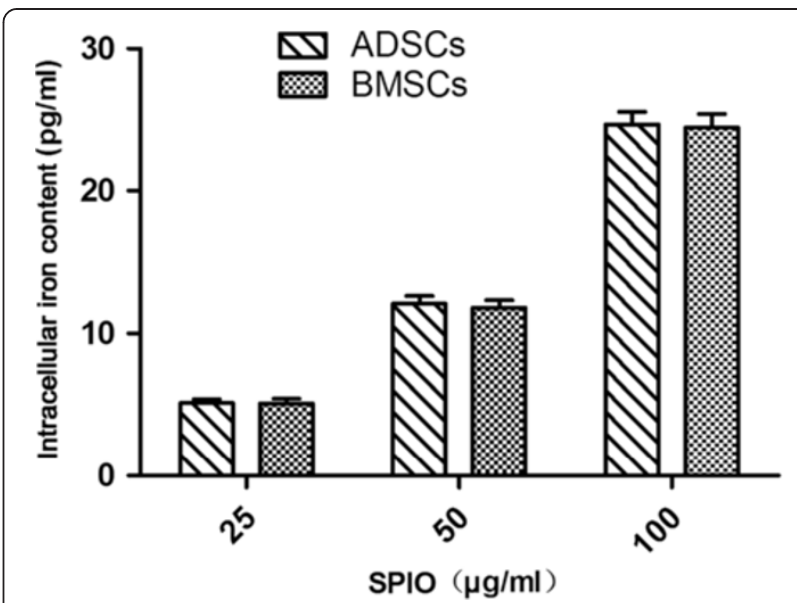

Figure 4 Intracellular iron content measured with a total iron reagent set.

The viability of cells decreased with increasing concentrations of SPIOs $(P<0.05)$. However, the viability of the two kinds of cells showed no significant difference (Group 1: $t=0.533 ; P>0.05$; Group 2: $t=1.106 ; P>0.05$; Group 3: $t=0.773 ; P>0.05$; control group: $t=0.0002 ; P>0.05$ ) (Figure 5). Because of their higher labeling efficiency and viability, we chose the cells in Group 2 to measure the changes in adipogenic and osteogenic potential.

After induction, phase-contrast microscopy revealed bone nodes and lipid droplets in the cells. Bone nodes became smaller, whereas lipid droplets shrunk in size (Figure $6 \mathrm{a}$ and $\mathrm{b}$ ). The activity of ALP decreased (ADSCs: $t=5.433 ; P<0.05$; BMSCs: $t=6.217 ; P<0.05$ )

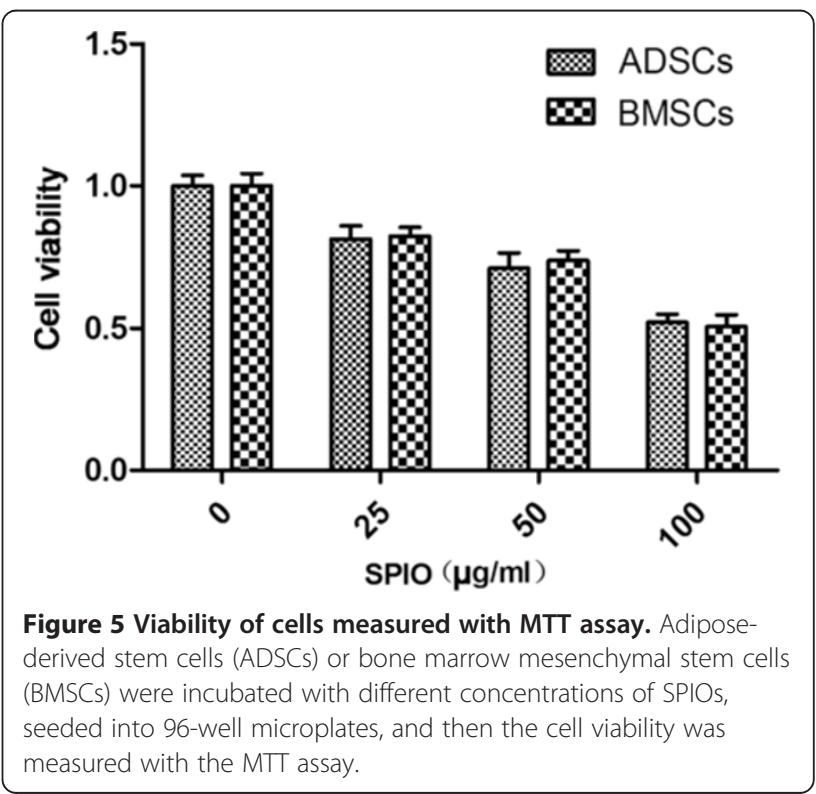




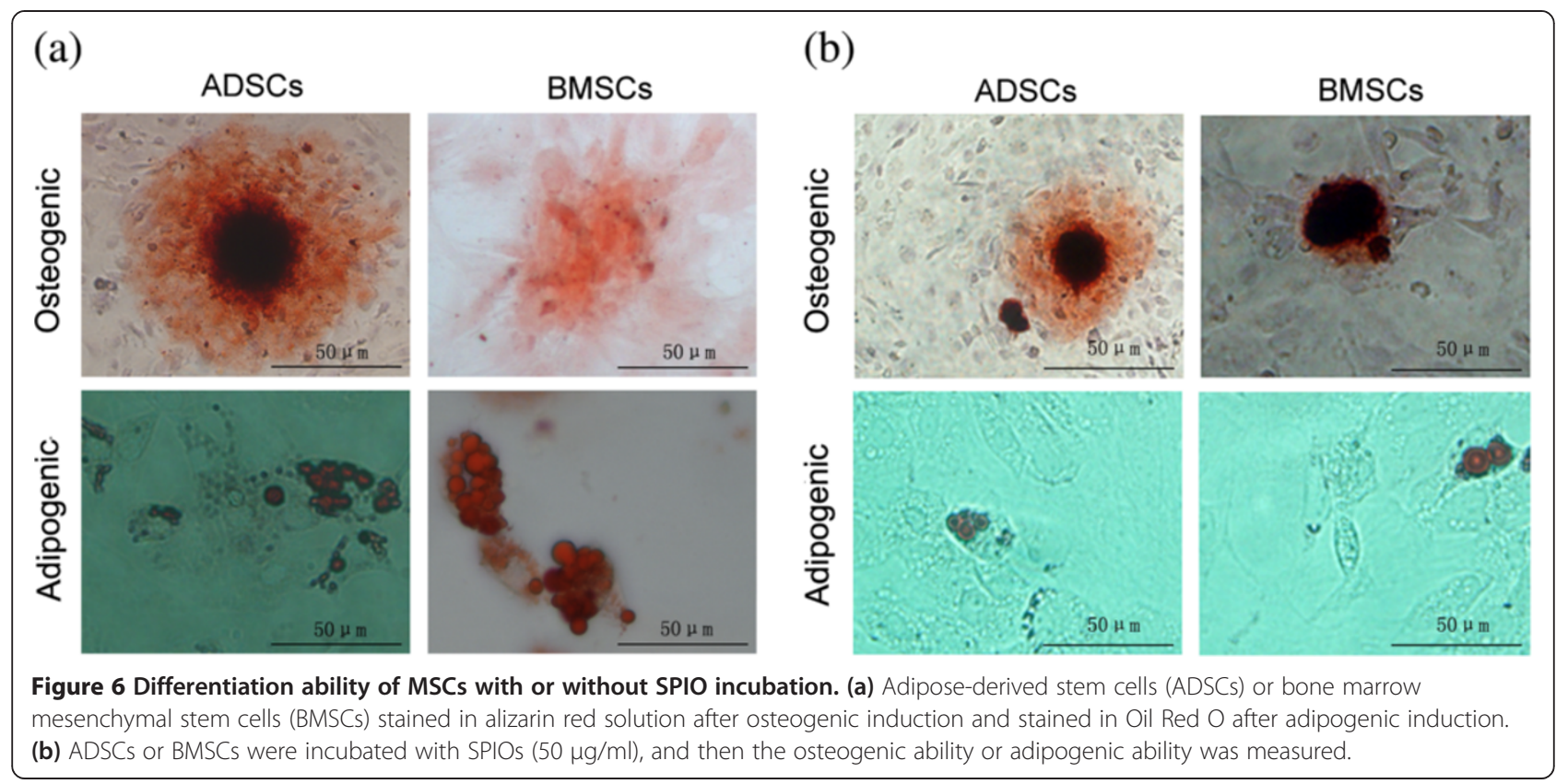

(a)

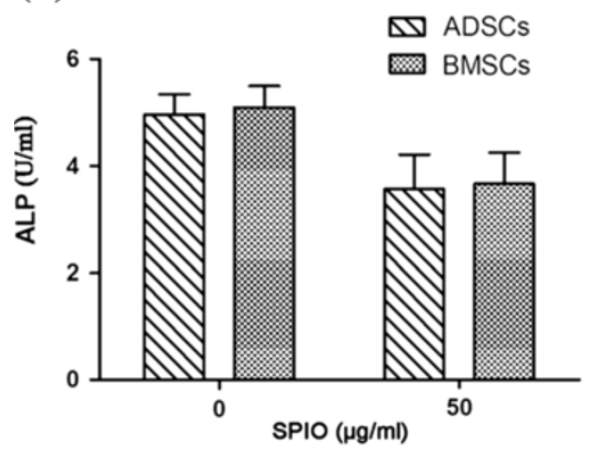

(c)

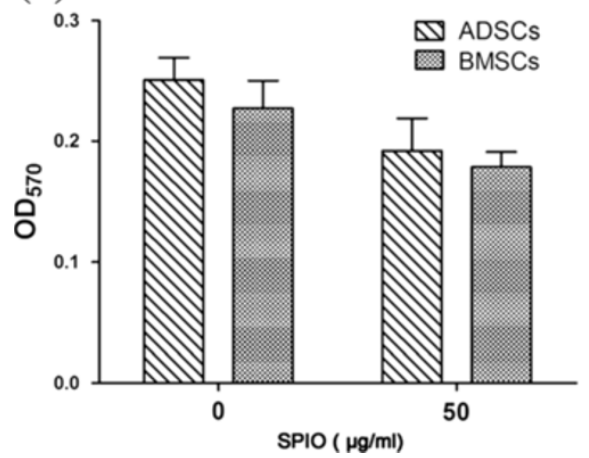

(b)

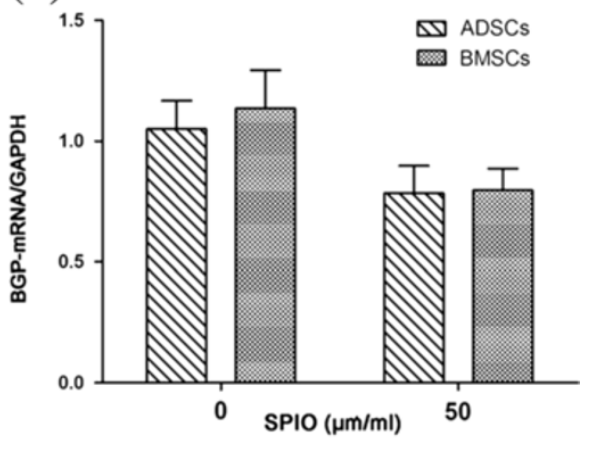

(d)

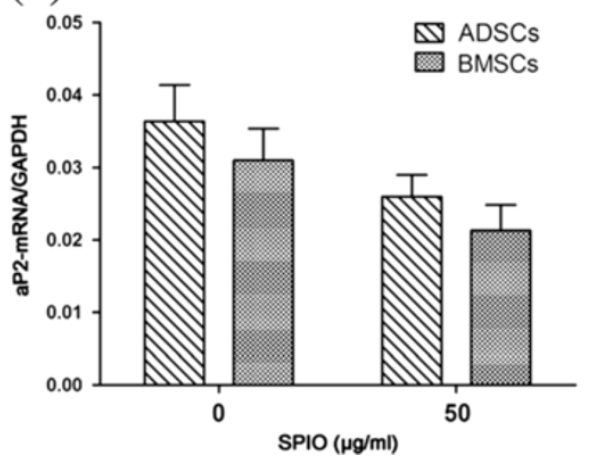

Figure 7 Analysis of osteogenic and adipogenic ability. Adipose-derived stem cells (ADSCs) or bone marrow mesenchymal stem cells (BMSCs) were incubated with or without SPIOs (50 ng/ml). (a) Activity of ALP in two kinds of cells after osteogenic induction. (b) Real-time PCR analysis of BGP-mRNA after osteogenic induction. (c) OD value of lipid droplets after adipogenic induction. (d) Expression of aP2-mRNA after adipogenic induction. 
(Figure 7a), as did the expression of BGP-mRNA (ADSCs: $t=4.383 ; P<0.05$; BMSCs: $t=5.419 ; P<0.05$ ) (Figure $7 \mathrm{~b}$ ). Thus, the osteogenic potential of cells after SPIO labeling decreased. The OD value of lipid droplets decreased (ADSCs: $t=5.171 ; P<0.05$; BMSCs: $t=5.404$; $P<0.05$ ) (Figure 7c), as did the expression of aP2-mRNA (ADSCs: $t=4.992 ; P<0.05$; BMSCs: $t=4.830 ; P<0.05$ ) (Figure $7 \mathrm{~d}$ ). Thus, the adipogenic potential of cells after SPIO labeling decreased. However, the differentiation potential of the two kinds of cells showed no significant difference $(P>0.05)$, (ALP: $t=0.210 ; P>0.05$; BGP-mRNA: $t=0.156 ; P>0.05$; OD value: $t=0.872 ; P>0.05$; aP2-mRNA: $t=2.235 ; P>0.05$ ) (Figure 7a through d). Thus, ADSCs could withstand the toxicity of SPIOs as well as BMSCs.

Many studies have reported that high levels of SPIOs can affect the viability and differentiation of MSCs. Rice et al. [24] confirmed that cell viability decreased with increasing concentrations of SPIOs when iron concentrations exceeded $12.5 \mu \mathrm{g} / \mathrm{ml}$. Arhab et al. [31] found that cell viability was affected when iron concentrations of SPIOs reached $50 \mu \mathrm{g} / \mathrm{ml}$. Wang et al. [32] and Kostura et al. [33] suggested that SPIOs inhibit chondrogenesis of stem cells at high concentrations, whereas Chen et al. [34] assert that SPIOs inhibit osteogenesis of stem cells at high concentrations. Kim et al. [22] found that stem cell markers (Oct-4) and cell-surface markers (CD45) changed after SPIO labeling. The mechanism of this effect is unclear. Pawelezyk et al. [35] and Karlsson et al. [36] suggested the following possible reason: when the intracellular iron concentration is too high, the iron oxide nanoparticles can become toxic to cells through Fenton-type Haber-Weiss reactions caused by free-radical damage [37]. Thus, high levels of SPIOs can affect the viability and differentiation of MSCs. Choosing the ideal concentration of SPIOs and optimizing the physical and chemical characteristics of SPIOs are therefore important in the tracing of transplanted ADCSs. Nevertheless, the viability and differentiation of labeled ADSCs in our experiments appeared to be largely retained, with labeled ADSCs maintaining their "stem cell characteristics," suggesting that SPIO-labeled ADSCs offer promise for stem cell therapies.

\section{Magnetic resonance imaging of SPIO-labeled MSCs in vitro}

We found the intensity of the MR signal in control group cells to be similar to that of water. The signal intensity in SPIO-labeled cells decreased with increasing concentrations of SPIOs (Figure $8 \mathrm{a}$ ). The $\mathrm{R}_{2}{ }^{*}$ of SPIOlabeled MSCs increased with increasing concentrations of SPIOs $(P<0.05)$, but no significant differences appeared between the two kinds of cells (Group 1: $t=0.087$; $P>0.05$; Group 2: $t=0.328 ; P>0.05$; Group 3: $t=0.798$;

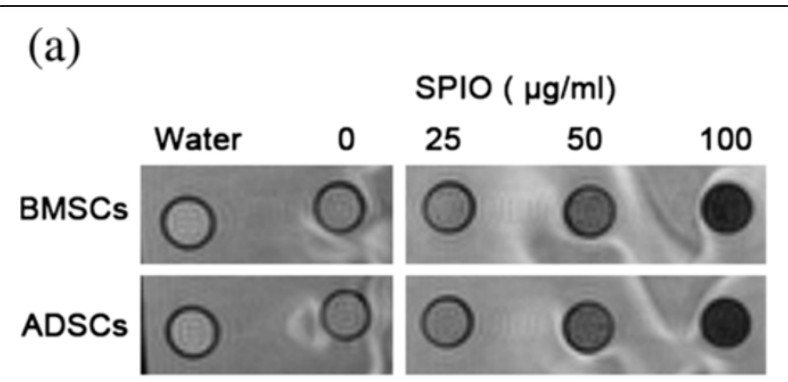

(b)

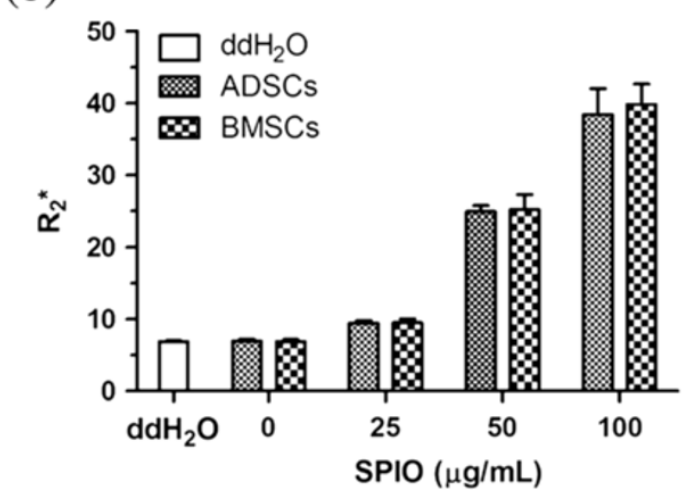

Figure 8 MRI of SPIO-labeled MSCs in vitro. (a) Adipose-derived stem cells (ADSCs) or bone marrow mesenchymal stem cells (BMSCs) were incubated with different concentrations of SPIO and then scanned with MRI. (b) R2* values of ADSCs or BMSCs in different groups were measured.

$P>0.05$; Group 4: $t=0.459 ; P>0.05$ ) (Figure 8b). Thus, MR imaging of SPIO-labeled ADSCs was virtually identical to that of BMSCs. MRI can reflect changes in intracellular iron concentrations, and so could be used to study changes in SPIO-labeled ADSCs in vivo. Further animal experiments should be undertaken to certify the influence of SPIOs on functions of ADSCs and BMSCs in vivo.

Our study certified that ADSCs have similar and comparative effects as BMSCs in vitro. Moreover, ADSCs have more-abundant sources and greater proliferation ability, compared with BMSCs. Once ADSCs are further confirmed to have effects comparable to those of BMSCs in vivo, ADSCs will be a significant option in stem cell application in clinical tracing and treatment.

\section{Conclusions}

In this study, we investigated the biological activity and MRI of SPIO-labeled ADSCs and compared these with BMSCs. We found that SPIO-labeled ADSCs were not statistically significantly different from BMSCs in terms of labeling efficiency, intracellular iron content, cell viability, differentiation, and MR imaging. Thus, ADSCs can be labeled and traced as easily as BMSCs in vitro. 
Given their abundance and higher proliferative capacity, as was previously shown [4-6,9], ADSCs may be better suited to stem cell therapy than BMSCs. When choosing between BMSCs and ADSCs for clinical therapies, these results should be taken into consideration in selecting the best MSCs for the treatment.

\begin{abstract}
Abbreviations
ADSC: Adipose-derived stem cell; ALP: Alkaline phosphatase; aP2: Adipocyte protein 2; BGP: Bone Gla protein; BMSC: Bone marrow mesenchymal stem cell; FBS: Fetal bovine serum; MRI: Magnetic resonance imaging; PDI: Polydispersity index; SPIO: Superparamagnetic iron oxide nanoparticle.
\end{abstract}

\section{Competing interests}

The authors declare that they have no competing interests.

\section{Authors' contributions}

JJF conceived and designed the experiments, performed the experiments, analyzed the data, and wrote the manuscript. YBT performed the experiments and analyzed the data. LYJ conceived and designed the experiments. XYW designed the experiments and analyzed the data. RSY contributed reagents/materials and revised the manuscript. MMZ conceived and designed the experiments, analyzed the data, and revised the manuscript. All authors read and approved the final manuscript.

\section{Acknowledgements}

The authors extend their sincere thanks for the financial support from National Natural Science Foundation of China (81171334 and 30770626).

Received: 17 November 2012 Revised: 21 March 2013

Accepted: 12 April 2013 Published: 23 April 2013

\section{References}

1. Staack A, Rodriguez LV: Stem cells for the treatment of urinary incontinence. Curr Urol Rep 2011, 12:41-46.

2. Gupta PK, Das AK, Chullikana A, Majumdar AS: Mesenchymal stem cells for cartilage repair in osteoarthritis. Stem Cell Res Ther 2012, 3:25.

3. Donnelly EM, Lamanna J, Boulis NM: Stem cell therapy for the spinal cord. Stem Cell Res Ther 2012, 3:24.

4. Taléns-Visconti R, Bonora A, Jover R, Mirabet V, Carbonell F, Castell JV, Gómez-Lechón MJ: Hepatogenic differentiation of human mesenchymal stem cells from adipose tissue in comparison with bone marrow mesenchymal stem cells. World J Gastroenterol 2006, 12:5834-5845.

5. Zuk PA, Zhu M, Ashjian P, De Ugarte DA, Huang Jl, Mizuno H, Alfonso ZC, Fraser JK, Benhaim P, Hedrick MH: Human adipose tissue is a source of multipotent stem cells. Mol Biol Cell 2002, 13:4279-4295.

6. Kern S, Eichler H, Stoeve J, Kluter H, Bieback K: Comparative analysis of mesenchymal stem cells from bone marrow, umbilical cord blood, or adipose tissue. Stem Cells 2006, 24:1294-1301.

7. Cowan CM, Shi YY, Aalami OO, Chou YF, Mari C, Thomas R, Quarto N, Contag CH, Wu B, Longaker MT: Adipose-derived adult stromal cells heal critical-size mouse calvarial defects. Nat Biotechnol 2004, 22:560-567.

8. Mitchell JB, McIntosh K, Zvonic S, Garrett S, Floyd ZE, Kloster A, Di Halvorsen Y, Storms RW, Goh B, Kilroy G, Wu X, Gimble JM: Immunophenotype of human adipose-derived cells: temporal changes in stromal-associated and stem cell-associated markers. Stem Cells 2006, 24:376-385.

9. Frölich K, Scherzed A, Mlynski R, Technau A, Hagen R, Kleinsasser N, Radeloff A: Multipotent stromal cells for autologous cell therapy approaches in the guinea pig model. ORL J Otorhinolaryngol Relat Spec 2011, 73:9-16.

10. van Buul GM, Kotek G, Wielopolski PA, Farrell E, Bos PK, Weinans H, Grohnert $A U$, Jahr H, Verhaar JA, Krestin GP, van Osch GJ, Bernsen MR: Clinically translatable cell tracking and quantification by MRI in cartilage repair using superparamagnetic iron oxides. PLoS One 2011, 6:e17001.

11. Balakumaran A, Pawelczyk E, Ren J, Sworder B, Chaudhry A, Sabatino M, Stroncek D, Frank JA, Robey PG: Superparamagnetic iron oxide nanoparticle labeling of bone marrow stromal (mesenchymal) cells does not affect their "stemness. PLoS One 2010, 5:e11462.

12. Kedziorek DA, Kraitchman DL: Superparamagnetic iron oxide labeling of stem cells for MRI tracking and delivery in cardiovascular disease. Methods Mol Med 2010, 660:171-183.
13. Wei H, Ooi TH, Tan G, Lim SY, Qian L, Wong P, Shim W: Cell delivery and tracking in post-myocardial infarction cardiac stem cell therapy: an introduction for clinical researchers. Heart Fail Rev 2010, 15:1-14.

14. Odintsov B, Chun JL, Mulligan JA, Berry SE: 14.1 T whole body MRI for detection of mesoangioblast stem cells in a murine model of Duchenne muscular dystrophy. Magn Reson Med 2011, 66:1704-1714.

15. Wimpenny I, Markides H, El Haj AJ: Orthopaedic applications of nanoparticle-based stem cell therapies. Stem Cell Res Ther 2012, 3:13.

16. Heyn C, Ronald JA, Ramadan SS, Snir JA, Barry AM, Mackenzie LT, Mikulis DJ, Palmieri D, Bronder JL, Steeg PS, Yoneda T, MacDonald IC, Chambers AF, Rutt BK, Foster PJ: In vivo MRI of cancer cell fate at the single-cell level in a mouse model of breast cancer metastasis to the brain. Magn Reson Med 2006, 56:1001-1010.

17. Shi XL, Gu JY, Han B, Xu HY, Fang LA, Ding YT: Magnetically labeled mesenchymal stem cells after autologous transplantation into acutely injured liver. World J Gastroenterol 2010, 16:3674-3679.

18. Dash R, Chung J, Chan T, Yamada M, Barral J, Nishimura D, Yang PC, Simpson PC: A molecular MRI probe to detect treatment of cardiac apoptosis in vivo. Magn Reson Med 2011, 66:1152-1162.

19. Guo J, Shen JK, Wang L, Xiao L, Zhang RJ, Luo WF, Gong ZG, Sun J, Xu H, Sirois $P$, Li K: In vivo evaluation of cerebral transplantation of resovistlabeled bone marrow stromal cells in Parkinson's disease rats using magnetic resonance imaging. Appl Biochem Biotechnol 2011, 163:636-648.

20. Reddy AM, Kwak BK, Shim HJ, Ahn C, Lee HS, Suh YJ, Park ES: In vivo tracking of mesenchymal stem cells labeled with a novel chitosancoated superparamagnetic iron oxide nanoparticle using 3.0T MRI. J Korean Med Sci 2010, 25:211-219.

21. Yao Y, Li Y, Ma G, Liu N, Ju S, Jin J, Chen Z, Shen C, Teng G: In vivo magnetic resonance imaging of injected endothelial progenitor cells after myocardial infarction in rats. Mol Imaging Biol 2011, 13:303-313.

22. Kim HS, Oh SY, Joo HJ, Son KR, Song IC, Moon WK: The effects of clinically used MRI contrast agents on the biological properties of human mesenchymal stem cells. NMR Biomed 2010, 23:514-522.

23. Wang L, Deng J, Wang J, Xiang B, Yang T, Gruwel M, Kashour T, Tomanek B, Summer R, Freed D, Jassal DS, Dai G, Glogowski M, Deslauriers R, Arora RC, Tian G: Superparamagnetic iron oxide does not affect the viability and function of adipose-derived stem cells, and superparamagnetic iron oxide-enhanced magnetic resonance imaging identifies viable cells. Magn Reson Imaging 2009, 27:108-119.

24. Rice HE, Hsu EW, Sheng H, Evenson DA, Freemerman AJ, Safford KM, Provenzale JM, Warner DS, Johnson GA: Superparamagnetic iron oxide labeling and transplantation of adipose-derived stem cells in middle cerebral artery occlusion-injured mice. Am J Roentgenol 2007, 188:1101-1108.

25. Răcuciu M, Creangă DE, Airinei A: Citric-acid-coated magnetite nanoparticles for biological applications. Eur Phys J E Soft Matter 2006, 21:117-121.

26. Spencer ND, Gimble JM, Lopez MJ: Mesenchymal stromal cells: past, present, and future. Vet Surg 2011, 40:129-139.

27. Pittenger MF, Mackay AM, Beck SC, Jaiswal RK, Douglas R, Mosca JD, Moorman MA, Simonetti DW, Craig S, Marshak DR: Multilineage potential of adult human mesenchymal stem cells. Science 1999, 284:143-147.

28. Bäckesjö CM, Li Y, Lindgren U, Haldosén LA: Activation of Sirtl decreases adipocyte formation during osteoblast differentiation of mesenchymal stem cells. J Bone Miner Res 2006, 21:993-1002.

29. Ye YX, Bogaert J: Cell therapy in myocardial infarction: emphasis on the role of MRI. Eur Radiol 2008, 18:548-569.

30. Suh JS, Lee JY, Choi YS, Yu F, Yang V, Lee SJ, Chung CP, Park YJ: Efficient labeling of mesenchymal stem cells using cell permeable magnetic nanoparticles. Biochem Biophys Res Commun 2009, 379:669-675.

31. Arbab AS, Bashaw LA, Miller BR, Jordan EK, Lewis BK, Kalish H, Frank JA: Characterization of biophysical and metabolic properties of cells labeled with superparamagnetic iron oxide nanoparticles and transfection agent for cellular MR imaging. Radiology 2003, 229:838-846.

32. Wang HH, Wang YX, Leung KC, Au DW, Xuan S, Chak CP, Lee SK, Sheng H, Zhang G, Qin L, Griffith JF, Ahuja AT: Durable mesenchymal stem cell labelling by using polyhedral superparamagnetic iron oxide nanoparticles. Chemistry 2009, 15:12417-12425.

33. Kostura L, Kraitchman DL, Mackay AM, Pittenger MF, Bulte JWM: Feridex labeling of mesenchymal stem cells inhibits chondrogenesis but not adipogenesis or osteogenesis. NMR Biomed 2004, 17:513-517. 
34. Chen YC, Hsiao JK, Liu HM, Lai IY, Yao M, Hsu SC, Ko BS, Chen YC, Yang CS, Huang DM: The inhibitory effect of superparamagnetic iron oxide nanoparticles (Ferucarbotran) on osteogenic differentiation and its signaling mechanism in human mesenchymal stem cells. Toxicol Appl Pharmacol 2010, 245:272-279.

35. Pawelezyk E, Arbab AS, Pandit S, Hu E, Frank JA: Expression of transferrin receptor and ferritin following ferumoxides-protamine sulfate labeling of cells: implications for cellular magnetic resonance imaging. NMR Biomed 2006, 19:581-592.

36. Karlsson HL, Gustafsson J, Cronholm P, Moller L: Size-dependent toxicity of metal oxide particles: a comparison between nano- and micrometer size. Toxicol Lett 2009, 188:112-118.

37. Apopa PL, Qian Y, Shao R, Guo NL, Schwegler-Berry D, Pacurari M, Porter D, Shi X, Vallyathan V, Castranova V, Flynn DC: Iron oxide nanoparticles induce human microvascular endothelial cell permeability through reactive oxygen species production and microtubule remodeling. Part Fibre Toxicol 2009, 6:1-14.

doi:10.1186/scrt191

Cite this article as: Fan et al:: Biological activity and magnetic resonance imaging of superparamagnetic iron oxide nanoparticles-labeled adipose-derived stem cells. Stem Cell Research \& Therapy 2013 4:44.

\section{Submit your next manuscript to BioMed Central and take full advantage of:}

- Convenient online submission

- Thorough peer review

- No space constraints or color figure charges

- Immediate publication on acceptance

- Inclusion in PubMed, CAS, Scopus and Google Scholar

- Research which is freely available for redistribution

Submit your manuscript at www.biomedcentral.com/submit
() Biomed Central 